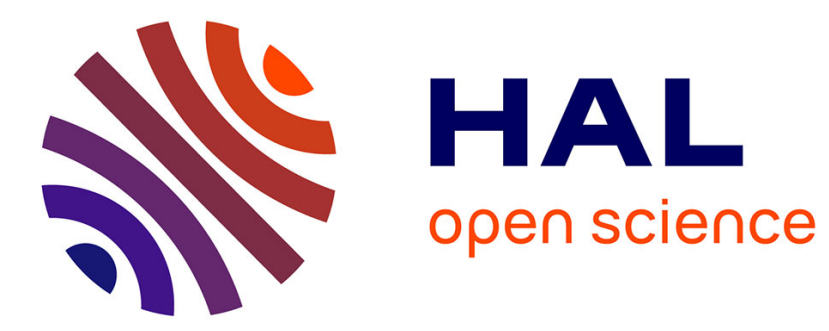

\title{
The tsunami named CRISPR/Cas9
}

H. Chneiweiss

\section{To cite this version:}

H. Chneiweiss. The tsunami named CRISPR/Cas9. Revue Neurologique, 2018, 174 (7-8), pp.487-488. 10.1016/j.neurol.2018.04.006 . hal-01799815

\section{HAL Id: hal-01799815 https://hal.sorbonne-universite.fr/hal-01799815}

Submitted on 25 May 2018

HAL is a multi-disciplinary open access archive for the deposit and dissemination of scientific research documents, whether they are published or not. The documents may come from teaching and research institutions in France or abroad, or from public or private research centers.
L'archive ouverte pluridisciplinaire HAL, est destinée au dépôt et à la diffusion de documents scientifiques de niveau recherche, publiés ou non, émanant des établissements d'enseignement et de recherche français ou étrangers, des laboratoires publics ou privés. 


\section{The tsunami named CRISPR/Cas9}

It is rare to witness a breakthrough technology that results in a multidimensional revolution in human health that also has impacts on animals and plants as well as biodiversity and the environment. The tsunami associated with the latest genomeediting techniques is most likely not comparable to anything we have known thus far. In addition, the technology is not only relatively easy to deploy, but also developing at a dizzying pace.

Targeting the genome to change the sequence of a gene and its pattern of expression is not new. But, without question, the use of CRISPR (clustered regularly interspaced short palindromic repeats)/Cas9 [1] represents a major technological revolution. Indeed, this is the latest advance of a technology that allows the specific addition, removal or modification of DNA sequences, summarized by the term 'genome editing' [2]. If the genome-edited sequence corresponds to a gene, then the amino-acid sequence of the protein encoded by the gene may then be altered and, in some cases, lead to changes in its activity and function and/or its location or lifespan. Conversely, genome editing may result in the correction of the defective function of a gene within a specific biological context.

CRISPR/Cas9 induces a double-strand break in DNA at selected sites in the genome of any cell of any species. In practice, guide RNA (gRNA) leads the DNA endonuclease Cas9 to a specific sequence with instructions to cut through the DNA strands. The gRNA must be complementary to the chosen target sequence and located next to a short DNA sequence motif called 'PAM' (protospacer adjacent motif) to allow Cas9 to bind to the target genomic locus. The cell may then use two different mechanisms to repair the break: non-homologous end joining (NHEJ); or homology-directed repair (HDR). If the objective is to knock down the targeted gene expression, it is sufficient to allow NHEJ to mend the break. However, as NHEJ is prone to error, the 'repaired gene' will most likely be mutated by the insertion and/or deletion (INDEL) of random nucleotides. If the objective is to correct a preexisting mutation, then the repair has to restore the 'normal' sequence. To do this, HDR requires the introduction of a template DNA sequence, thereby allowing the cell to repair the break by copying the template sequence. This also applies when introducing a mutation to mimic a gene variant.

Given this rather simple scheme, the imagination of researchers seems to be without limits, as many technical adaptations have already been made to, for example, simultaneously modify multiple targets, use a dead Cas9 molecule, drive the increased/decreased expression of a gene, or of a fluorophore [3], or develop a programmable CRISPR system (RCas9) capable of specifically eliminating the toxic RNAs causing dominantly inherited diseases such as myotonic dystrophy type 1 or 2 (DM1/2), Huntington's disease or C9orf72-linked amyotrophic lateral sclerosis (C9-ALS) [4]. Virtually all branches of the life sciences will soon be penetrated by the rapid development of genome-editing technologies. For humans, genetic changes in somatic cells, germ cells and embryos are clear targets for these new approaches. As for other animals, both livestock and laboratory animals are likely candidates for these new methodological approaches, and the environment and biodiversity will also be clearly among the potentially affected areas. Gene drive approaches where a CRISPR/Cas9 cassette is able to self-perpetuate, thereby rapidly spreading any genetic information 
among all members of a given population, could be applied for pest control, although this should also raise concerns over its misuse. Of equal concern is that gene-editing technologies could be used for the development of genetic weapons of mass destruction. Several academic institutions and ethics committees, including the US National Academy of Sciences (NAS)/National Academy of Medicine (NAM) ${ }^{1}$ and, more recently, the European Academies Science Advisory Council (EASAC) ${ }^{2}$, have addressed the ethical, legal and social aspects (ELSA) raised by these new genomeediting tools. Based on its own report published in December 2015, the INSERM ethics committee organized a meeting in Paris, on 16 March 2016, with a wide range of European stakeholders to reflect upon and foster responsible research using genome-editing technologies [5].

The first ethical concern is to assess the feasibility, efficacy and safety of genomeediting techniques so that the benefit-to-harm balance of any potential clinical application can be properly evaluated. Because we still lack complete control over CRISPR/Cas9 binding and NHEJ vs HDR intervention after cutting DNA, there is a need to evaluate on-target variants, any potential off-target (cuts at non-selected sites) effects and mosaicisms (partial cuts resulting in different daughter cells, some repaired and some not), as well as epigenetic effects, in both the short and long term. Before such studies are promoted, however, there is a need to define standardized methods. To this end, we called for the establishment of a European Steering Committee (ESC) of experts from a wide range of relevant disciplines as diverse as molecular and cell biology, ecology and a variety of the social sciences $[5,6]$. In addition, the ESC should rely on an open and transparent discussion process, including representatives of patient organizations, ethics committees and the economic sector, as well as of the communications sector.

A major ethical question is the potential application of genome-editing techniques to humans embryos. France, along with many other member countries, ratified the Oviedo Convention of the Council of Europe, including its Article 13, which is relevant to germline genome editing [6]. The Article prohibits any genetic modification that might be heritable. However, we believe that now is the time for open discussion of a case-by-case analysis for a limited number of genetic disorders, such as Huntington's disease, which may be prevented by genome editing. Clearly, this is necessary for society to maintain its general confidence in science, and requires the appropriate oversight of any laboratory work or medical application of genomeediting techniques, especially those that are irreversible and permanent.

The field of neurology will be impacted by genome-editing techniques in multiple ways. It will allow us to rapidly and easily design cellular and animal models of human neurological and mental disorders with known genetic bases, including most neurodegenerative as well as neurodevelopmental disorders. The new techniques are also changing the game for gene therapy, with ongoing clinical trials of muscular dystrophies, for example.

Another ethical challenge is to control the present overhyping of genomeediting techniques. Making certain therapeutic promises may engender dystopian expectations. Thus, it is important to raise awareness of the clear distinction between the care/treatment of human diseases and human enhancement.

Finally, attention needs to be drawn to the philosophical concept that opposes the dynamism and plasticity of all living organisms by adhering to the inadequate idea of a human nature founded solely on biological determinism. To do this, we must also

\footnotetext{
1 https://www.nap.edu/catalog/24623/human-genome-editing-science-ethics-and-governance

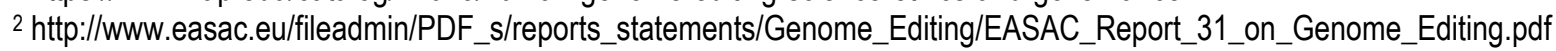


foster more debates both within the scientific community and with the rest of civil society.

Hervé Chneiweiss, MD PhD

Sorbonne Universite, UPMC Univ Paris 06 Institut de Biologie Paris Seine (IBPS)

Neuroscience Paris Seine, UMR CNRS 8246, INSERM 1130 F-75005, Paris, France Office tel: 3314427 5294/Cellular: 33682213045

http://www.ibps.upmc.fr/fr/Recherche/umr-8246

\section{References}

1. Mojica, F.J. and L. Montoliu, On the Origin of CRISPR-Cas Technology: From Prokaryotes to Mammals. Trends Microbiol 2016; 24: 811-20.

2. Gaj, T., C.A. Gersbach, and C.F. Barbas, 3rd, ZFN, TALEN, and CRISPR/Cas-based methods for genome engineering. Trends Biotechnol 2013; 31: 397-405.

3. Barrangou, R. and J.A. Doudna, Applications of CRISPR technologies in research and beyond. Nat Biotechnol, 2016; 34:933-941.

4. Batra, R., et al., Elimination of Toxic Microsatellite Repeat Expansion RNA by RNATargeting Cas9. Cell, 2017; 170: 899-912 e10.

5. $\quad$ Chneiweiss, H., et al., Fostering responsible research with genome editing technologies: a European perspective. Transgenic Res 2017; doi: 10.1007/s11248017-0028-z.

6. Hirsch, F., Y. Levy, and H. Chneiweiss, CRISPR-Cas9: A European position on genome editing. Nature 2017; 541: 30. 